\title{
ACCOUNTING ASPECTS OF THE PECULIARITIES OF THE FUNCTIONING OF INTERNET-SHOPS IN MODERN CONDITIONS
}

\author{
Elena DROZDOVA ${ }^{1}$ \\ Odessa Institute of Trade and Economics, Ukraine
}

\begin{abstract}
Under modern conditions, characterized by the development of information technologies, the approach to trade activity has been changing fundamentally as its movement to the virtual reality brings changes in the sphere of management and determines the organization of accounting. The current pace of development of computer systems and technologies has led to the development of e-commerce, the possibility of function of which is provided by the information systems. Methodology of research, analysis of last researches and publications. Rapid growth of e-commerce market and the existence of practical issues concerning the organization and the peculiarities of functioning of the appropriate entities have been formed a scientific interest in the task solving. The need for accounting approach to e-commerce activity subjects has been identified the relevance of research. The purpose of research is to generalize the researches regarding the e-commerce and its components, formation of a common understanding of organization and the features of e-commerce business entities with the definition of the accounting aspects in order to ensure efficiency. Subject of research. In the article the essence of e-commerce and peculiarities of its implementation in connection with the development of e-commerce in Ukraine and in the world has been considered. The activity of Internet-shops as one of the most popular e-commerce systems has been researched. Advantages, disadvantages and feasibility of functioning of Internet-shops compared to other systems have been identified. The place and role of accounting as well as the features of its organization in creating of Internet-shop have been determined. The features of accounting according to the different ways of payment have been considered. Results of research. The development of e-commerce in Ukraine and in the world contributed to the development of the activities of Internet-shops as one of the most common of its systems. The ability to save money and time when buying goods contributed to factors of this kind of e-commerce system in Ukraine. However, during the organization of this type of trade it is important to take into account the negative impacts, one of them - the need to develop electronic payment systems. Organization of operation of Internet-shops has a number of features and in the first place it is provided by the Internet-site that initially requires an investment, but in the future development minimizes costs and is more efficient and less expensive way of doing business in the modern world. In the research the different aspects of Internet-shops, taking into account the methods and organization of accounting, have been considered, the possible expenses at the beginning of activity and in the further development of this type of trade have been identified, the various ways of purchase by customers, that determine in complex the characteristics of functioning of the Internet-shop, have been considered. Thus, accounting in modern conditions being still a source of high-quality (accurate, timely) information for management system has been developing and transforming in parallel with changes in the types of business, appearance of new objects and requests for information by appropriate users. In the article the peculiarities of the activities of the online shops in modern conditions have been considered, in further research the other types of such business models should be more studied. In addition, as e-trade is actively growing, the analysis of problematic issues becomes the main tasks: pricing, product range, delivery and payment.
\end{abstract}

Key words: accounting, e-trade, e-trade systems, Internet-shops, e-commerce, e-commerce market.

JEL Classification: M40, M41, O31

\footnotetext{
Corresponding author:

${ }^{1}$ Department of Accounting, Auditing and Statistics, Odessa Institute of Trade and Economics.

E-mail: lena_drozdova@ukr.net
} 


\section{Problem definition}

The computer system and technologies development influences the all types of activity and actual development temps caused to the electronic business formation and the opportunity the existence of which is provided by information systems.

According to the Ukrainian association evaluation the direct Marketing Association (UDMA) total market e-commerce by the end of 2014 amounted to $1.6 \mathrm{bln}$. dollars. (It's included in the scope of the B2C-only sale of new goods). In comparison with the 2013, the market of e-commercial grew up to the $19 \%$ but in the dollars cheeped for $20 \%$. A lot of segments are recessed because of UAH hard fall. Considering the economic situation stabilization, the e-commerce market volume to 20162018 , is foreseen to positive tendency: $2016-\$ 1.4 \mathrm{bln}$., 2017 - \$1.8 bln., 2018 - 2.3 bln. dollars (UDMA, 2014). The common tendencies witness about the functioning of the e-commerce market and Ukraine's integration to the global processes.

By the foresee of a lot of other experts in 2016, the Internet trade in money equivalent will reach the point of 5,65 bln. dollars. In Ukraine there are 8000 shops that sell almost any product, but most of them are small players in the market are not able to provide a significant level of investment in marketing and advertising, infrastructure and logistics (Boychuk, 2014). Currently, the most common type of e-commerce is the sale of goods and services through the activities of online stores. This distance selling includes many features and uses, as a system that requires a comprehensive approach to the organization of its operation, and in the subsequent development.

The speeded up of e-commerce and existing of practical questions about organization and features of the activities of relevant stakeholders to formulate a scientific interest in the problem solving.

In a way, such tendencies of Internet development in Ukraine are studies by O.V. Boychuk (Boychuk, 2014), the features of stakeholder e-commerce is considering T.V. Bochulia (Bochulia, 2013), e-commerce in the field of information services examined LL Intercession, A.A. Kopachev (Pokrovskaia, Kopachev, 2014), accounting and tax aspects of the online shopping study Yu.A. Kudryavtseva, S.V. Pelkova (Kudryavtseva, Pelkova, 2014), V.V. Khudoleev (Khudoleev, 2003) and others.

The necessity of accountancy approach to the activity of electronic trade defined the actuality of carried out research. The goal of research is the informational generalization in connection with systems of e-commerce and its components the formation of a common understanding of the organization and characteristics of the subjects of e-commerce activities, the definition of the accounting aspects in order to ensure efficiency.

\section{Tendencies of e-commerce development in Ukraine}

In the modern conditions with specific development of informational technologies, the approach to the trade activity is essentially changed, because its movement in the virtual reality brings changes in the sphere of management and determines the organization of accounting.

Learning the especially the organization of accounting and taxation treatment of trade organizations costs, T.V. Dedova (Dedova, 2005) means that in the system of state market relations is a set of trade organizations is the main link between the production and consumption of products. As a source of cash income, sale forms are the basis of the financial stability of the state.

The advantages of alternative trade activity functioning are the Internet shopping is studying T.V. Bochulya (Bochulya, 2013), calling such: for the buyer - costs saves time and money for the seller - the savings on rent and commercial premises maintenance, payment of personnel and other expenses associated with the conduct of commercial activities.

Internet - is a trade has own legal, accounting and tax features, is developed last times and it's appeared more and more online retailers. Internet shops - it's the enterprises and organizations engaged in trade via the Internet (Khudoleev, 2003).

Learning the features of e-commerce, L.L. Pokrovskaia, A.A. Kopachev (Pokrovskaia, Kopachev, 2014) focused attention that traditional methods of doing business in today's economy is not fully in line with trends in the development of organizations.

Electronic commerce is able to essentially increase the economic efficiency of enterprises. Researchers define that the implementation on the enterprise the e-commerce methods of business allows increasing the efficiency of promoting goods and services, to expand markets, develop a relationship with customers, helping to reduce ongoing costs, reducing the total time of customer service and order processing.

According to the Khudoleev V.V. definition (Khudoleev, 2003), the trading through the Internet has the list of practical features:

- sale of goods produced mainly natural persons;

- link the buyer and seller there is no direct, personal contact by using different means of communication;

- lack of internet-shop real trading platform;

- implementation of the delivery of the goods to the buyer;

other features of e-commerce.

\section{Internet-markets as the system of e-commerce}

Traditionally e-commerce systems in the consumer's sector (B2C) are the electronic strip mall (supermarket), 
Internet storefronts and Internet stores. The organization of market activity and implementation of certain system depends on the daily transactions number which defines the opportunity each of independent business with the help of Internet storefronts and automation of all processes and the functioning of the respective Internet stores.

Internet-store needs the official web-page with online sales function which is possible to be carried out in two ways: creation of an electronic sale point or its renting. In the first case developers wages, premiums charged with such salaries, payment of a domain name for your site (the special name of the site), the cost of hosting (storage services pages on the site on a dedicated server on the Internet) are the expenses. It also includes the other expenses which are connected with developing (Kudriavtseva, Pelkova, 2014). In the case when the online store is rented, the rent expenses per month are got (Kudriavtseva, Pelkova, 2014).

In the same time the e-commerce trade supposes the permanent support in adjusted site operation, tracksystems by site visits accounting and individual products pages on the basis of the principle of personalization and profiling technologies to further analysis and possible management decision-making, cooperation with delivery services, online counselling clients.

The qualitative consumer consultation, especially in the Internet-stores activity, is the key task because quick servicing and informing encourage the competition advantages in the actual competitive conditions. The servicing tasks are the professional consulting, quick order execution.

\section{Organizational aspects of accountancy in Internet stores}

The accountancy is the source of informational formation about enterprise activity with the purpose of future control and use for management decisions. The importance of such information forming is defined by the market competition, the predominant choice of the buyer, and the influence of external factors in the market, highrisk conditions of uncertainty in the business. The risks influence may be avoided or minimized having qualitative information which the reliability, timeliness, volume define the main characteristics.

It's widely known that information is the priority productive factor which defines classic land, labour, capital. Together with the entrepreneurship abilities as the productive factors form the most powerful competitive potential development of economic activity in the modern conditions.

Traditionally the elements of accountancy define the primary accountancy, document circulation, inventory, chart of accounts, forms of accounting, reporting.

The accountancy of Internet stores activity is not the exception and the head of company is responsible for its organization and legislation leading considering the features of sale volumes and specific of Internet stores,

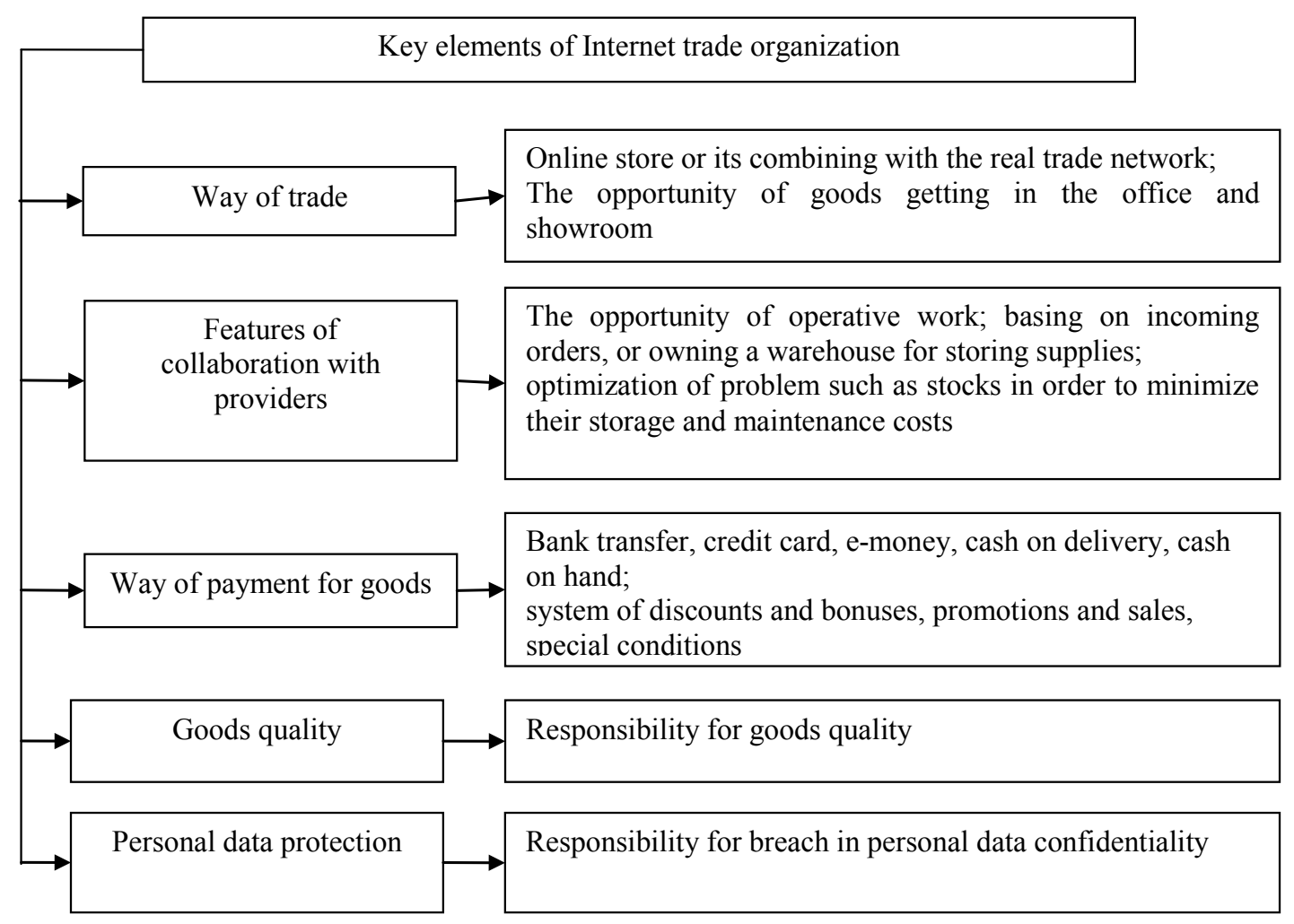

Fig. 1. Features of Internet trade organization and web page functioning 
defines the necessity of accountancy service creation or leads the accountancy personally and also outsourcing (which is considered below)

The accountancy leading for Internet stores originally consists of taking into account the cost of website creation and its functioning depends on the conditions. In dependence of existence of outstanding rights for web page and it's defined as non-material active or future periods expenses.

By the way, the accountancy organization depends on the its features of web page functioning (fig. 1).

The differentiation of payments ways for consumers is the main above mentioned moments because it forms the completive advantages in connection with the suitableness of purchase payment. In the same time, the use of bank payment is the easiest way of payment for Internet store. That's why with the goal of such way popularization, some Internet stores use sales pitch-is the additional bonuses or discounts for customers who prefer this method of payment.

Internet store accountancy may be carried out by the introduction of the state of their own accountants (financial services), or the financial company (outsourcing). The Internet stores activity is new enough in this reason the directing should to define the advantages and disadvantages in every methods considering the cost of services, the volume of work, qualified professionals.

According to the definition of V.F. Trunina and V.A. Starodubtseva (Trunina, Starodubtseva, 2013), the accountancy provides the qualitative service with the essential economy of money in connection with unnecessary equipment costs jobs, special software and literature, payroll staff accountant and finance training and refresher courses. In connection with the minimization of costs, there is a time-saving, labor resource, which allows us to develop more effectively.

The strengthening concentration of internal corporate focus on the main purpose of the company by delegating responsibilities for accounting outsourcer, which positively encourage business, are watched in the organization. Such company as a rule has the staff of highly qualified specialists with wide job experience which is accumulated by the similar tasks solving which means the essential risk recession in correctness of accounting operations and reporting distortion (Trunina, Starodubtseva, 2013).

Researching the accountancy in outsourcing, T.I. Kisilevich (Kisilevich, 2011) focuses attention on that small and medium businesses are essentially interested in outsourcing development, as large companies create institutions serving them on different types of consulting, analysis, accounting, etc., as well as enter into contracts with organizations, transferring to outsource not only accounting, but also a number of other non-core functions.

By the way, the work of personal accountant or accounting service of Internet store is often needed automation and purchases the finished product, the use of rented services. Such necessity is defined by the scale of operations and additional tasks in the accountancy organization: conducting book expenses and income, the formation of the amount of taxes, registration of goods in the context of suppliers and buyers, and others.

\section{Conclusions and perspectives}

E-commerce dynamic in Ukraine and world encouraged the development of Internet stores activity as one of the most distributed system. The opportunity in money and time economy by the goods purchasing is the establishing factors such e-trade in Ukraine. But during its organization, it's necessary considering the negative influences one of which is the necessity in e-payment system development.

Internet stores functioning organization has its list of features and is provided by the web page functioning which originally needs the investments but further progress in minimizing costs and is more efficient and less expensive way of doing business in the modern world.

In the researching it's considered the different aspects in Internet stores functioning, taking into account the ways and organization of accountancy, identified the possible expenses in the beginning of activity and in future such trade development, analyzed the different ways of goods payment by consumers which in combination define the features of Internet store functioning.

In a way the accountancy in modern conditions is still the informational source for administrative apparatus, developed and transformed in parallel with changes in the business, the appearance of new objects and requests for information relevant users.

Article considered the features of Internet store functioning in modern conditions, further studies should investigate in more detail other kinds of business models for trading by the Internet. By the way because such trade type is actively developed. The analyses of problematic moments became the priority task: pricing of products, product range, delivery and payment.

\section{References}

Boychuk, I.V. (2014). Directions of modern Internet development in Ukraine. Retrieved from: http://www.lac.lviv.ua/fileadmin/www.lac.lviv.ua/data/kafedry/Marketyngu/Docs/Kaf_Market_Presentation Bojchuk_2014.pdf

Bochulia, T.V. (2013). Accounts intricacies of trading Internet rating in economic subjects. Journal of «International Accounting», Moscow, 28(274): p. 55-62.

Dedova, T.V. (2005). Organization of accountancy and taxation cost treatment of trade organizations: dis. Cand. Econ. Sc., Voronezh, 178 p. 
Kisilevich T.I. (2011). Accountancy on the outsourcing. Magazine «Audit and Financial Analysis”, № 4, 2011. Retrieved from: http://www.auditfin.com/fin/2011/4/2011_IV_02_05.pdf

Kudriavtseva, Yu.A., Pelkova, S.V. (2014). Features of goods sale organization by the Internet under the simplified system of taxation. Journal of «International Journal of Applied and Basic Research", 7: 92-95.

Pokrovskaia, L.L. (2014). E-commerce in the sphere of informational services: monograph, M.-Berlin: DirectMedia, $182 \mathrm{p}$.

Trunina, V.F., Starodubtseva, V.A. (2013). Advantages and disadvantages of accountancy outsourcing in Russia. Young Scientists, № 1: p. 192-194. - Retrieved from: http://www.moluch.ru/archive/48/5990/

Khudoleiev, V.V. (2003). Legal, accounting and tax aspects of the online stores. Journal «Accounting and Taxes in the trade and public catering", № 4. Retrieved from: http://www.buntorg.ru/articles/2003/4/3474.html

What happened to the e-commerce market of Ukraine for 2014 and what to expect at the end of 2015 / Ukrainian Direct Marketing Association (UDMA). Retrieved from: http://www.uadm.com.ua/wp-content/ uploads/2015/07/e-commerce-pdf

\section{Елена ДРОЗДОВА}

\section{УЧЕТНЫЕ АСПЕКТЫ ОСОБЕННОСТЕЙ ДЕЯТЕЛЬНОСТИ ИНТЕРНЕТ-МАГАЗИНОВ В} СОВРЕМЕННЫХ УСЛОВИЯХ

Аннотация. В современных условиях с характерным развитием информационных технологий, кардинально меняется подход к торговой деятельности, поскольку ее перемещение в виртуальную реальность несет изменения в сферу управления и определяет организацию бухгалтерского учета. Актуальные темпы развития компьютерных систем и технологий привели к формированию электронного бизнеса, возможность существования которого и обеспечивается информационными системами. Методика исследования, анализ последних исследований и публикаций. Ускоренный рост рынка электронной коммерции и существование практических вопросов по поводу организации и особенностей деятельности соответствующих субъектов сформулировали научный интерес к решению поставленных задач. Необходимость учетного подхода к деятельности субъектов электронной торговли определили актуальность проведенного исследования. Целью исследования является обобщение информации касательно системэлектронной коммерции и ее составляющих, формирование общего понимания организации и особенностей деятельности субъектов электронной торговли, определение учетных аспектов с целью обеспечения эффективности. Предмет исследования. В статье рассмотрена сущность электронной торговли и ее особенности в связи с развитием электронной коммерции в Украине и в мире. Исследована деятельность Интернет-магазинов как одной из наиболее распространенных систем электронной коммерции. Выявлены преимущества, недостатки и целесообразность функционирования Интернет-магазинов по сравнению с другими системами. Определено место, роль бухгалтерского учета и особенности его организации при создании Интернет-магазина. Рассмотрены особенности организации бухгалтерского учета при различных способах оплаты. Главные результаты и выводы исследования. Динамика электронной коммерции в Украине и мире способствовала развитию деятельности Интернет-магазинов как одной из наиболее распространенных ее систем. Факторами становления такого вида электронной торговли в Украине является возможность экономии денежных средств и времени при покупке товаров. Однако при ее организации важно учитывать негативные влияния, одно из которых - необходимость развития системы электронных расчетов. Организация функционирования Интернет-магазинов имеет ряд особенностей и, в первую очередь, обеспечивается работой Интернет-сайта, что изначально требует инвестиций, но в дальнейшем прогрессе минимизирует расходы и является более эффективным и менее затратным способом ведения торговли в современных условиях. В исследовании рассмотрены разные аспекты деятельности Интернетмагазинов, учитывая способы и организацию бухгалтерского учета, идентифицированы возможные расходы в начале деятельности и в дальнейшем развитии такого вида торговли, проанализированы различные способы оплаты покупок клиентами, что в комплексе определяет особенности функционирования Интернет-магазина. Таким образом, бухгалтерский учет в современных условиях, по-прежнему являясь источником качественной (точной, своевременной) информации для управленческого аппарата, развивается и трансформируется параллельно с изменением видов деятельности, появлением новых объектов и информационных запросов соответствующих пользователей. В статье рассмотрены особенности деятельности Интернет-магазинов в современных условиях, в дальнейших исследованиях более детально следует изучить другие разновидности бизнес-моделей для торговли через Интернет. Кроме того, поскольку такой вид торговли активно развивается, приоритетным заданием становится анализ проблемных моментов: формирование цен на продукцию, ассортимент продукции, способ доставки и оплаты. 